Marquette University

e-Publications@Marquette

English Faculty Research and Publications

English, Department of

$10-1-2014$

\title{
Beauty and the Beastly Prime Minister
}

John J. Su

Marquette University, john.su@marquette.edu

Published version. ELH: English Literary History, Vol. 81, No. 3 (Fall 2014): 1083-1110. DOI. C 2014 Johns Hopkins University Press. Used with permission. 


\section{BEAUTY AND THE BEASTLY PRIME MINISTER}

BY JOHN SU

If there was any doubt whether former Prime Minister Margaret Thatcher's shadow continues to loom large over Britain, the events of 2011 provided the answer. The riots over the summer in London, with their echoes of the Brixton riots 30 years before, have meant that comparisons between Prime Minister David Cameron and Thatcher are now inevitable. Thatcher's image in popular culture continues to circulate in musicals such as Billy Elliot and has recently been given new life in the biopic The Iron Lady, starring Meryl Streep. References to her have been increasing in conservative media outlets in Great Britain and the United States. The American Senator John Kyl, for example, declared in the National Review that his country "can find inspiration in what she did." Congresswoman and Republican presidential candidate Michele Bachmann branded herself "America’s Iron Lady" in an attempt to shore up her candidacy, underscoring the cultural capital that continues to be associated with the image of the former Prime Minister. Restored within the Conservative pantheon-now perhaps more unambiguously than at any time since she was forced to stand down by members of her own party-Thatcher demands renewed attention from literary and cultural theorists.

The literary afterlife of Thatcherism extends into at least the first decade of the twenty-first century, exemplified by works such as Alan Hollinghurst's The Line of Beauty (2004) and Zadie Smith's On Beauty (2005). The initial enthusiasm for Tony Blair's "Cool Britannia" notwithstanding, literary texts continue to portray the "Thatcher revolution" as the most significant shift in British politics and culture since the so-called postwar settlement-a revolution whose consequences continue to be felt even though Thatcher herself had long since retired from public life prior to her death in 2013. Indeed, with the eclipse of postmodernism as a significant periodizing concept for authors and scholars alike, it is increasingly apparent that (as Thatcher herself might have put it) "there is no alternative": contemporary British literature is defined in terms of responses to a set of political, economic, and cultural forces associated with Margaret Thatcher. ${ }^{2}$ 
The coincidence of Hollinghurst's and Smith's titles points to one of the most complex and unresolved issues in the study of contemporary British literature: what might be described as the "turn to beauty" in response to Thatcherism. The highly touted, though probably overstated, "turn" in the 1990s in a wide variety of arts is well known. ${ }^{3}$ In literature, it manifested in several ways: the neo-pastoral of Julian Barnes, Ian McEwan, and Kazuo Ishiguro; the quasi-metaphysical rhetoric of David Hare and Tom Stoppard; the eroticized imagery of Hanif Kureishi. Hare's own evolution from his early days with the Portable Theatre Company is emblematic of a broader phenomenon, one captured in his 2003 response to the question "what is political theatre?" posed by the Guardian: "Failure is our element. Theatre has changed as little as society. Yet many of us have ended up curiously buoyant, not, let's hope, consoled but embraced by the beauty of what we are attempting, in art as much as in politics." ${ }^{4}$ The turn to beauty, here, is cast explicitly as a response to repeated failures in the political arena- a shift away from a more direct political polemic against Thatcherism in favor of a more indirect, rarefied oppositional stance.

To understand why the concept of beauty has proved so compelling to critics of Thatcherism requires moving beyond entrenched tendencies in the humanities to view the notion of beauty as part of an aesthetic that is fundamentally apolitical, or at best naïvely conceived. Without minimizing the remarkable resurgence in scholarship on aesthetics in the past decade, the critique has deep roots in literary studies, from Walter Benjamin to the anti-aesthetic strain of postmodernism articulated by Hal Foster and others. It also has a more specific location within debates on the left in Britain. While Christopher Norris's 1990 What's Wrong with Postmodernism: Critical Theory and the Ends of Philosophy is remembered for its critique of Jean Baudrillard and other postmodern luminaries, one of its primary targets was the "New Times" movement associated with the journal Marxism Today for its purported betrayal of socialist values. Following Perry Anderson, Norris lamented what he saw as a turn to aesthetics on the left: "The recourse to aesthetics would then appear little more than a desperate holding operation, a means of continuing to talk, think and theorise about issues of a vaguely political import while serenely ignoring the manifest 'fact' that socialism is everywhere in a state of terminal decline. ${ }^{.5}$ Efforts by left-leaning cultural critics to use aesthetic models in order to raise questions in the realm of socio-political theory, Norris suggests, can be seen as part of an ideological retrenchment across a range of cultural and socio-political institutions that effectively 
demobilizes resistance to Thatcherism. Cultural critics, in other words, become implicit apologists for the status quo they claim to critique.

I will argue that the basic error in this line of reasoning is the underlying assumption that aesthetics is an abstract, ahistorical category. The terms of aesthetic theory have highly specific histories; even the unwieldy, multifarious notion of "beauty" takes on particular resonances in light of the cultural, political, and economic circumstances in which it is invoked. ${ }^{6}$ The turn to beauty in contemporary British fiction, then, does not represent a flight from politics or a facile utopianism. Rather, it provided authors the means to examine the increasing disillusionment with the postwar consensus since the 1970s. This is not to say that there is a uniform, homogeneous sense of beauty among the authors in this essay, and my analysis will highlight an important shift in antiThatcher representations: a melancholic, though frequently ironized, longing for the restoration of the postwar consensus characterizing fiction of the 1990s; a more ambivalent, post-utopian desire to find an alternative to postwar consensus in the idea of a common humanity characterizing fiction of the 2000s. The vocabulary of beauty in these literary works speaks less to shared values than to the relentlessness with which Thatcher pursued an agenda that raised socio-political questions with which theories of beauty historically have been concerned: What produces a "common sense" or consensus? What motivates people to make the judgments they do? And what dimensions of life are not encompassed by commodity exchange? Put another way, the prevalence of notions of beauty in contemporary British fiction is the direct result of Thatcherite appeals to greed (according to her critics) or individual liberty, forcing reflection on what might be described as the affective, nonrational bases of citizenship. Beauty functions in these literary works, in other words, neither as a content nor a form, as it has often been conceived in Western aesthetics. Nor even is it a kind of negative category intended to evoke a noninstrumental world, as envisioned by Theodor Adorno. It is, rather, a far less coherently defined concept whose significance emerges in relation to an opposing term, beastliness.

\section{THE RHETORIC OF BEASTLINESS}

Cognizant of Claire Berlinski's assertion that "No two Thatchers are exactly alike," I would nonetheless like to highlight an undertheorized dimension common among critical portrayals of her-what I am calling her beastliness. ${ }^{7}$ Thatcher's purported inability to demonstrate aesthetic appreciation or otherwise to value beauty has been widely noted, though 
often seen as peripheral to or symptomatic of her political beliefs. The novelist Anthony Burgess, for example, declared: "Mrs. Thatcher is herself a notorious philistine. . . . There is no poetry in her, as there was in Disraeli and Churchill." Philistinism was a recurring charge among authors and academics alike, who found the Prime Minister "packaged together in a way that's not exactly vulgar, just low."9 Oxford University denied Thatcher an honorary degree, even while presenting degrees to other heads of state including the American president Bill Clinton. The portrayal of her beastliness was not hard to make stick because it aligned with her own self-presentation as a grocer's daughter, working hard to manage a household on a budget, hoarding necessities in her pantry against potential shortages. Thus, her policies toward the arts-including direct cuts to art subsidies; indirect cuts through abolishing the Greater London Council and Metropolitan counties, which had been responsible for significant subsidies; and initiating changes to the Arts Council, so that it more explicitly embraced the idea of an arts industry providing a return on investments through tax revenues and tourism-came to have a broader significance for how Thatcherism was viewed. ${ }^{10}$

Thatcher's purported inability to have aesthetic experience was reinforced through portrayals of her physical ugliness. Perhaps the iconic example would be the grotesque puppet of her that appeared in the TV series Spitting Image. Similar characterizations appeared in political cartoons, pop songs, and literary texts. She was a hectoring nanny with an overbite, mad hair, and a strident, pile driver voice- "Maggie the Bitch," to recall Salman Rushdie's cutting description. ${ }^{11}$ Consistent with Heather Nunn's observations about the multiple and often conflicting images of Thatcher, opposing images were simultaneously circulating: Christopher Hitchens famously proclaimed Thatcher's sexiness; Philip Larkin adored her; Kingsley Amis was enraptured by what he saw as her unearthly beauty, much to the bemusement of his son Martin. ${ }^{12}$ But assertions of her beauty were often coupled with affective responses bordering on disgust, even among admirers. Complimenting her skin and skill with makeup, journalist Paul Johnson nonetheless lamented that she was a "compendium of annoying habits." 13 It is for this reason, then, that I use the term beastliness to describe characterizations of Thatcher rather than ugliness, though the two are often synonymous in portrayals of her. As we will see more fully later, even when Thatcher is portrayed as sexy or beautiful, her beauty is cast as instrumental to political policies devoted to promoting greed and undermining consensus. 
Characterizations of beastliness enabled her critics to conflate Thatcher as a person, the policies she enacted, and shifts in global capitalism more generally. This conflation is apparent, for example, in two of the most well-known novels of the era, Martin Amis's Money: A Suicide Note (1984) and Hanif Kureishi's The Buddha of Suburbia (1990). Amis's money-obsessed, hard-living advertising executive turned movie director John Self proudly declares: "I'm the new kind, the kind who has money but can never use it for anything but ugliness," thereby rendering equivalent greed, ugliness, and the political climate that enabled his gross misbehaviors. ${ }^{14}$ Kureishi's protagonist, Karim Amir, similarly turns to the language of ugliness to condense a variety of phenomena he observes around him: "London was being ripped apart . . . and the new was ugly."15 It is striking to note that neither text needs to portray Thatcher herself in order to register its critique of Thatcherism. The Buddha of Suburbia simply alludes in its final paragraphs to a television announcement of the new Prime Minister occurring in the background of a family party. The 1970s are over, the passage suggests: the budding instances of greed, consumerism, and xenophobia that Karim had experienced as an individual over the course of the novel are cast as harbingers of the pervasive enterprise culture of the 1980s.

Nor was this conflation confined to literary texts: the Labour Party utilized similar tactics, literally rendering the Prime Minister as the face of greed. In 1989, then Labour front-bencher Gordon Brown wrote a critique of Thatcher policies entitled Where There Is Greed, which pictured the Prime Minister on the front cover. ${ }^{16}$ The image of Thatcher's body served as a convenient visual shorthand. Various manifestations of "greed," which have a complicated variety of sources and motivations, are conglomerated into a single image that must be supported or rejected wholesale. To reject greed and excess is to reject Thatcher, and vice versa. On the level of image production, then, the interests of Thatcher's supporters and critics coincided to a remarkable degree: to fashion a coherent image of Thatcherism that could encompass a disparate group of political, social, and economic interests.

The key point to recognize is that the rhetoric of beastliness provides a frame for understanding references to beauty in the literary works on which I will focus in the remainder of this essay-works that often define beauty in vague terms, if at all. Put another way, anti-Thatcher representations frequently invoked beauty in order to mobilize the affective disgust associated with ugliness or beastliness. This is apparent in what Dominic Head and others take to be the 
most significant novel about the effects of Thatcherism, Jonathan Coe's What a Carve Up! (1994; in the United States, the novel was retitled The Winshaw Legacy: or, What a Carve Up!). The novel portrays the efforts by writer Michael Owen to compose a family history of the aristocratic Winshaw family. The Winshaws, as Head writes, are "caricatures of the new unethical elite, and together they represent the full range of social devastation, which the novel lays at the door of the Thatcher era." 17 Over the course of the novel, it is revealed that the Winshaw family is behind a host of national ills, from stockmarket scandals to arms deals with Iraq, the cheapening of serious media, deliberately poisoning the food supply, and the loss of standards in the art market. Brief descriptions of Owen's nostalgic childhood home outside Birmingham's outermost suburbs and a seaside holiday in the similarly idyllic setting of Eastbourne do appear as counterpoints to the portrayals of global capitalism that dominate What a Carve Up!, but such interludes are neither the focus nor the endpoint of Coe's novel. Indeed, the novel takes pains to portray the personal beastliness of each of the Winshaws, emphasizing thereby the permeation of Thatcherite policies of deregulation and privatization across a wide swath of industries and institutions. In other words, the concept of the beautiful enables literary texts to render amorphous global phenomena into a concrete image of beastliness against which to stand.

\section{NEW LEFT MELANCHOLY: 1990S}

The beautiful/beastly opposition has been a central strategy in contemporary British fiction to delineate possible boundaries to the forces of neoliberalism with which Thatcherism is associated. Drawing on one of the most established tropes in British fiction, What a Carve Up! projects an alternative, more communitarian set of values onto the realm of the beautiful - the English countryside. In so doing, Coe follows E. M. Forster, D. H. Lawrence, and John Fowles in mapping social tensions onto the geography of the nation. In their works, the countryside becomes the repository for vague, sentimental notions of shared responsibility over individual gain. This "Green England," to borrow Fowles's term, always exists in a state of temporal disjointedness: physically present in often dilapidated forms such as the country house past its prime, the fullest expression of national community is accessible only through its fragmentary remains. ${ }^{18}$ In What a Carve Up!, the alternative vision of Englishness is projected onto what the novel simply refers to as "the farm." ${ }^{19}$ Owen's childhood memories, 
which he himself notes are the product of "nostalgic glamour," identify in rural England a communitarian world whose more holistic notion of economics permits greater attention to cultivating human relationships than commodity exchange $(W, 159)$. These memories, combined with the brief seaside excursion with his neighbor and burgeoning love interest Fiona, are all explicitly cast as fragments of a lost past. Fiona herself will die before their love is consummated-one more victim of the Winshaws and their efforts to defund the National Health System. The beauty associated with both Fiona and rural England is guaranteed by their unambiguous separation from the beastly world of the Winshaws and current events-most notably, the bombing that commences the first Iraq war.

Julian Barnes's England, England (1998) stages this bifurcation even more explicitly than Coe's novel, physically separating the two Englands: the materialistic, consumerist version is moved to the Isle of Wight and renamed "England, England"; the rural, communitarian version remains where England historically has stood, and is now renamed "Anglia." Isolating itself from the European Union and global capitalism, Anglia becomes the space identified with beauty: "Chemicals drained from the land, the colours grew gentler, and the light untainted; the moon, with less competition, now rose more dominantly. In the enlarged countryside, wildlife bred freely. . . . Common law was reestablished."20 By aligning the countryside with beauty, Barnes portrays a seemingly nonideological basis for consensus. On this account, consensus emerges organically as individuals are separated from an economic system that values consumption. The novel satirically though genuinely posits the identification of shared interests as part of human nature, not something that requires explicit political mobilization. ${ }^{21}$ The "Fête" that the villagers create for themselves is apolitical, noninstrumental, and has no particular purpose other than leisure. ${ }^{22}$ Rather than the consumption-based leisure associated with tourism and the heritage industry of "England, England," leisure in Anglia is associated with games, family activities, and picnics. Consumption is not, then, the default tendency of human nature; it is an activity rather than the basis of identity, and it may cease when no longer encouraged by the media and government. More precisely, Barnes maps the abstract theoretical opposition between beauty and beastliness onto two different models of national identity, what might be described as the beautiful citizen of Anglia in contrast to the beastly consumer of England, England. In so doing, Barnes establishes citizenship as something literally "natural": the reestablishment of common law—with 
its associations of tradition, shared values, and mutual consent-is portrayed simply as the logical consequence of restoring the natural beauty of the English countryside.

The implied opposition between a beautiful citizen and a beastly consumer reinforces a notion that Thatcherism was not an inevitable phenomenon, but one produced through the complicity of those who know better. In Barnes's novel, the England, England project is headed by Sir Jack Pitman, entrepreneur and Thatcher-man extraordinaire. Yet the success of the project depends upon the participation of Martha Cochrane, someone acutely aware of Sir Jack's ego and greed. Her participation costs her dearly in terms of personal happiness, and there is no surprise on her part or the readers' that she is ultimately exiled from England, England. In Coe's novel, complicity with Thatcherism is highlighted even among its victims. At the bloody climax of the novel, Mortimer Winshaw declares to Owen:

[T] here comes a point, where greed and madness become practically indistinguishable. One and the same thing, you might almost say. And there comes another point, where the willingness to tolerate greed, and to live alongside it, and even to assist it, becomes a sort of madness too. Which means that we're all stuck with it, in other words. $(W, 485)$

As Ryan Trimm suggests, Owen cannot "properly forge connections between the emotional privations of his own life and the 'carve-ups' of Thatcherism and the Winshaws" until he is able to perceive his own complicity. ${ }^{23}$ Indeed, Owen's growing awareness of how global events and national economic policies have concrete, everyday consequences is the central trajectory of the second half of the novel. He ultimately recognizes that the responsibility for Fiona's death is not to be laid on the chance misfortune of illness or the underfunded National Health System, but on the totality of Thatcherism as part of a global neoliberal project - a project that he unwittingly supports in everyday activities from food choice to livelihood.

The emphasis in these novels on complicity is further highlighted by their assertions that right-wing politics is not based on conviction or a genuine belief in publicly articulated policies. Coe takes pains to show that the Winshaws privately repudiate their public sentiments and political positions: the agribusiness mogul Dorothy promotes fast food and industrial slaughterhouses, but keeps a select herd of free-range animals for her own consumption. The text emphasizes the Winshaws' hypocrisy: "Like Hilary (who never watched her own television programs), Dorothy had no intention of ever consuming the 
products which she was happy to foist upon an uncomplaining public" $(W, 253)$. Even among the staunchest supporters of Thatcherism, publicly stated positions are simply a means of sanitizing more basic affective appeals. Dorothy's cousin Henry Winshaw, for example, switches party allegiance from Labour to Conservative not because of evolving convictions, but because of personal attraction. On hearing Thatcher speak, Henry finds himself staring at her "like some sexstarved pubescent" (W, 128). Nor does his subsequent enthusiastic support of efforts to depose the Prime Minister in 1990 represent a reversal of position or inconsistency. His fickleness is a marker of consistency, as is the intensity underlying his declaration, "Dump the bitch" (W, 141). The repudiation of Thatcher as a political figure is simultaneously an affirmation of Thatcherism as an ideology.

Because What a Carve Up! and England, England refuse to acknowledge that support for Thatcher could come from genuine convictions or needs, the alternatives to Thatcherism become rendered as beautiful objects projected onto a lost past, to be mourned in a present moment defined by cynicism and moral bankruptcy. ${ }^{24}$ Put another way, pastoralism in Coe's and Barnes's fiction presupposes a certain melancholia: the putatively "natural" or nonideological basis of consensus can be based on a notion of human nature and its aesthetic proclivities, but to do so requires acknowledging that it is everywhere perverted by the complicity of individuals who compromise in the name of perceived self-interest. The implied opposition between a beautiful citizen and a beastly consumer thereby risks reproducing elements of the aesthetic ideology that helped to sustain class formations since the eighteenth century. It might be worrisome in this regard that when England, England is describing the future of Great Britain, it can do so only by self-consciously recycling pastoral tropes of rural Englishness. As Colin Hutchinson notes, fantasies of communitarian values often conceal the more difficult aspects of class antagonism. Reading Coe's novel, Hutchinson argues: "[T]he novel carries with it the danger of simply reinforcing that sense of the triumphant omnipotence and ubiquity of contemporary capitalism which infects so many social novels of the 1980s and 1990s." ${ }^{25}$ The portrayals of complicity in What a Carve Up! and England, England are not accompanied by anything resembling a development of class consciousness or a move toward political activism. Awareness is cast in personalized, almost metaphysical terms-Thatcherism is a zeitgeist more than a political ideology.

The pervasive irony in the novels serves to reinforce rather than undercut an opposition between the beautiful citizen and beastly 
consumer. As I have argued elsewhere, irony has been a crucial part of the pastoral tradition dating back to Virgil and Theocritus, and plays a crucial role in the neo-pastoralism apparent in contemporary British fiction. ${ }^{26}$ Barnes takes particular pains to show that the pastoral life of Anglia is a fiction, even to its inhabitants: Martha repeatedly notes how cultural traditions are invented on the spot by the likes of Jez Harris, a one-time junior legal expert from Milwaukee who is now embracing his inner yeoman. But Barnes also demonstrates great care in identifying for readers certain English historical traditions that are excluded from Anglia, most notably religiosity. Martha is portrayed as a regular churchgoer, but unambiguously an atheist. Residents are keen to have religion as a cultural practice, but make very clear to Reverend Coleman and the novel's readers that genuine religious belief is not on the table. Barnes's care in crafting Anglia, then, points to how much the novel has invested in portraying an alternative to Thatcherism, even one that cannot be straightforwardly endorsed. Barnes's curious, sometimes torturous efforts in England, England to clarify what cannot be included in the nostalgic past (churchgoing, yes; actual religious belief, no) indicates that irony is not intended to undercut the differences between a beautiful citizen and a beastly consumer; rather, it guarantees such difference by opening up an unbridgeable split between a real present and a pastoral past, in which the beautiful citizen is contained.

The implications of pastoralism are crucial to the conjunction of the literary, cultural, and political that I have been tracing in this essay. Particularly after Thatcher's reelection in 1983, an implicit pastoralism was apparent in many political commentaries coming from the left. Despite the sagging economy and continuing high levels of unemployment, Thatcher was able to win reelection, much to the despair of those who had argued that Britons would reject her once they knew her policies. E. P. Thompson's lament is telling: “This has not only been a nation of bullies. It has been a nation of poets and inventors, of thinkers and scientists, held in some regard in the world. It has been, for a time, no less than ancient Greece before us, a place of innovation in human culture." ${ }^{27}$ Thompson is keenly aware of the ways in which Thatcher's electoral victory depended on mobilizing affect around a particular kind of patriotism, one that identified the fullest expression of Britain's "greatness" in its former empire. So, Thompson's opposition between a past of cultural achievement and a present of entrepreneurial success is not a naïve gesture or statement of political resignation. Rather, it represents a means of establishing an 
alternative basis for political consensus by attempting to disaggregate Thatcher's claims to represent England from a notion of Englishness. On this understanding, quasi-pastoral tropes provide the means to contest the alignment of Englishness and Tory politics by casting the countryside as a repository of cultural rather than nationalist identity. Without conflating the concerns of novelists and cultural critics, we can nonetheless recognize the same basic strategy for delineating limits to neoliberalism. Thompson opts not for the opposition of a beautiful citizen and the beastly consumer per se, but a "nation of poets" and a "nation of bullies." In so doing, Thompson exemplifies moves made by a number of thinkers on the left including Michael Ignatieff, Stuart Hall, and Martin Jacques, who similarly recognized that the central ideological gesture of Thatcherism was its claim to represent a much broader and more unified constituency than was actually the case. ${ }^{28}$

I am suggesting, then, that political narratives of British cultural studies and the New Left are inseparable from narratives of literary history. The effort to revive a materialist history from pastoral tropes is made most famously by Raymond Williams in The Country and the City, who argued that the titular opposition is central to the emergence of capitalism: "The division and opposition of city and country, industry and agriculture, in their modern forms, are the critical culmination of the division and specialisation of labour which, though it did not begin with capitalism, was developed under it to an extraordinary and transforming degree." ${ }^{29}$ Williams, of course, was a defining figure in the formation of British cultural studies, influencing Hall and others. But the coincidence of fictional texts, literary history, and New Left thinking extends beyond the personalities who created the field of cultural studies ${ }^{30}$ As Alan Sinfield compellingly argued, literature was a centerpiece of the newly universalized national culture on which postwar consensus depended for its legitimacy and stability. The very fact that literature provided a means for expressing a critique of the dehumanizing effects of capitalism helped to make the postwar accommodation possible, whereby welfare capitalism could be seen as an acceptable alternative to the protracted, perhaps impossible task of overthrowing the system of capitalism itself. ${ }^{31}$ Sinfield's own Literature, Politics, and Culture in Postwar Britain (1989) was in many respects emblematic of a shift within literary studies in response to Thatcherism, reading political history in relation to shifts in literature. Hence, Sinfield could diagnose political crises in narrative terms: "It is because of those perceived political and economic failures that Margaret Thatcher has been elected and re-elected: people came to 
distrust the endless manipulations practiced by 'consensus' politicians in their attempts to keep all the balls in the air at once. . . . The old stories failed." 32 More than a triumph of policy, Thatcherism's success is cast as the result of a rhetorical failure on the part of the Labour Party. Thus, literary history and cultural critique on the left become intertwined, mutually affirming and reinforcing their defining terms of analysis. ${ }^{33}$

Thompson's lament, and the responses it generated, thus clarify the stakes of my own analysis of beauty in contemporary British fiction. Remembered less in its initial formulation than through Paul Gilroy's influential critique in There Ain't No Black in the Union Jack (1987), Thompson's assertion underlines the complex and unstable nature of representing citizenship vis-à-vis quasi-pastoral images of the past. At stake for Thompson is the issue of citizenship and its affective bases. Can representations of citizenship be disentangled from images circulated by the state? Can the intense feelings associated with a shared image of a national past be mobilized for anti-imperialist ends? Gilroy categorically rejects appeals to such images, asserting that any rhetoric of "one nation" depends on establishing consensus by deliberately excluding racialized others. He has reiterated the same basic elements of the argument for more than twenty years; in Postcolonial Melancholia (2005), for example, he warns against a pathological longing to recycle images and tropes of the past. The continuing obsession in Great Britain with images of World War II, for Gilroy, represents not only a means of denying full citizenship to immigrants from former colonies and their children but also a technique for concealing Britain's more immediate and unappealing postwar imperialism. ${ }^{34}$ But Thompson's efforts to reclaim certain dimensions of Englishness for specifically antiimperialist ends-similar to efforts by scholars such as Eric Hobsbawm, novelists discussed in this essay, and others such as John Fowles and Peter Ackroyd—invites further reflection. Does the opposition between beauty and beastliness provide a frame for interpreting the effects of Thatcherite policies and diagnosing potential alternatives in a climate of political apathy? Or, does the necessarily selective representation of the past on which beauty depends simply reinforce ideological claims to a hegemony that is more putative than actual? For thirty years, a range of scholars including Hall, Bob Jessop, and David Childs have cautioned against consolidating Thatcherism-retrospectively granting it a monolithic status that underplays the evolution of the former Prime Minister's policies and sanitizes the past, enabling the convenient omission of the Labour Party's own turn to monetarism 
prior to Thatcher's election. The deliberate effort to envision "the farm" in What a Carve Up! or Anglia in England, England suggests that alternatives to Thatcher can emerge only retrospectively, in light of the devastating effects of her policies. But if the category of beauty enables representations of a utopian alternative to neoliberal Britain based on a selective representation of a past that never quite was, does this simply encourage the pleasurable apathy Benjamin derided as Linke Melancholie ("left melancholy") in the 1930s? ${ }^{35}$

\section{BEAUTY AFTER THE BEAST: 2000-?}

An implicit melancholia can be read even in recent representations of Thatcher and Thatcherism, which often portray her as not only the definitive figure of a decade in British political and cultural life but also a kind of trauma or ghostly presence that the nation has yet to work through. In the introduction to their 2010 edited collection, Louisa Hadley and Elizabeth Ho explicitly use the terminology, referring to the "traumatic effects" that Thatcher continues to generate. ${ }^{36}$ To some degree, this argument has always been in circulation, and was the basis for the New Times movement associated with Hall and Jacques, the editor of Marxism Today. Their core thesis that the 1980s signaled "New Times" - a fundamentally new, post-Fordist phase of capitalism-asserted that Britons experienced a radical and irreversible break with their past, if not explicit trauma. ${ }^{37}$ Similar arguments became widely apparent soon after the Prime Minister resigned in 1990-Barnes, for example, declared in 1993 that in the post-Thatcher era, "the pendulum continues to swing, but inside a clock that has been rehung on the wall at a completely different angle." ${ }^{38}$ Political cartoons portrayed Thatcher as an undead figure haunting each of her successors. In one particularly intriguing image appearing in The Guardian in 2000, Tony Blair is pictured attempting to drive a stake through the heart of Thatcher, who, although lying in a coffin, is simultaneously strangling Blair. ${ }^{39}$ The emerging consensus among political scholars that New Labour extended rather than challenged its Conservative predecessors-despite optimistic pronouncements by Labour leaders about a political "Third Way" that would move beyond the antinomy of classical social democracy (unflatteringly described as "the old left") and neoliberalism - can likewise be seen as a form of the same argument, that Thatcherism continues to dominate how political and cultural life in Great Britain can be understood. 
British fiction published since the early 2000s, however, increasingly eschews the metaphors of melancholia and trauma circulating in literary and cultural studies-suggesting a new, and perhaps final, stage in the literary afterlife of Thatcherism that this essay has been tracing. Novelists such as Hollinghurst do not deny that the effects of Thatcherism are still felt. In an interview with Stephen Moss, Hollinghurst declares that the 1980s "seems to have determined so many things about the way we live now." ${ }^{\text {"40 }}$ The shift in recent works including Hollinghurst's Line of Beauty and Smith's On Beauty, however, is apparent in the absence of rigid oppositions between a beautiful citizen and the beastly consumer. Both novels stage a political conflict in their early pages, but deflate significant ideological differences by highlighting personal similarities between the antagonists. In the case of The Line of Beauty, the novel stages conflict through the device of having young graduate student and self-described aesthete Nick Guest living in the household of Gerald Fedden, a fictionalized member of the new Tory MPs elected in the 1983 landslide that consolidated Thatcher's political power in the wake of the Falkland Islands campaign. But Hollinghurst's aesthete turns out to be no less narcissistic than the ambitious Conservative politician, both of whom engage in clandestine affairs with little concern for the consequences to others. In the case of On Beauty, the explicit "hommage" to Forster's Howards End signaled in Smith's acknowledgments establishes the expectation that the conflict between two families will trace broader social tensions. ${ }^{41}$ The Belseys and Kipps stand on opposite sides religiously, politically, and aesthetically; the patriarchs of the two familiesHoward Belsey and Monty Kipps-become representatives of what the novel describes as its own "culture war" occurring on the fictional liberal arts campus of Wellington $(O B, 156)$. But their debate becomes eclipsed by their personal lives, as the secular poststructuralist liberal Belsey is revealed to be governed by the same unrestrained libido as the religious conservative Kipps. The scandalous discovery that Kipps is having an affair with a student at Wellington is counterpointed at the end of the novel by the recollection of Belsey's earlier sexual episode with Kipps's daughter, Victoria or Vee.

On Beauty nonetheless portrays its central conflict as a consequence of Thatcherism. In the first scene to establish Kipps's political views, the novel focuses on his response to the Brixton riots of 1981-a defining moment of Thatcher's first administration. In a radio debate with Belsey's colleague and confidant Erskine Jegede, Kipps echoes Thatcher's dismissal of the riots as crimes perpetrated by irresponsible 
individuals, not protests against national policies or systemic racism. While the debates in the novel focus on signature American issues of free speech and affirmative action, the political rhetoric and reasoning of Kipps echoes Thatcher's. These echoes can be heard, for example, in his declaration that "[e]quality was a myth" $(O B, 44)$. Thatcherism is no longer portrayed as the driving ideological inspiration for a global neoliberalism in On Beauty - as it was in England, England and What a Carve Up! - but it remains a key element. The absence of references to Prime Minister Tony Blair means that the tensions over the gentrification of London described in section 3 of On Beauty are implicitly cast as a consequence of the Brixton riots and Thatcherite policies enacted in the 1980 s to promote an enterprise culture. The similar absence of references to American politicians or contemporary political contexts in the scenes set in the United States allows the debate between Belsey and Kipps over affirmative action to trace back to their earlier aesthetic debates and common connection to England. On Beauty thus repeats the tendency in Smith's writing since her first novel, White Teeth (2000), to avoid direct reflection on political events even while making what Philip Tew describes as "many fragmentary allusions" to a Thatcherite political and historical context. ${ }^{42}$

Recognizing the Thatcherite echoes in the novel is crucial to understanding its departures from Howards End. The difference is signaled in the very first scene, which begins in the same epistolary mode as Forster's novel to introduce the conflicting families. Updating the technology of correspondence, On Beauty portrays a chain of e-mails from Howard Belsey's eldest son, Jerome, to his father. As was the case with Howards End, the conflict centers on an aborted engagement between members of the families; however, the nature of the conflict is very different. From Jerome's first e-mail, a "feud" between the two families is identified $(O B, 5)$. Whereas the disputes between the Schlegels and Wilcoxes emerge out of the romantic entanglement that begins the novel, the disputes between the Belseys and Kippses trace back much further. The exact origins of the feud are unclear, and Jerome casts it as irrational. But their conflict is intractable in a way that is not apparent in Howards End-in no small part because of its underlying political axis. Long before their debates over the aesthetic value of Rembrandt, the two academics were split over politics: "Howard had always disliked Monty, as any sensible liberal would dislike a man who had dedicated his life to the perverse politics of right-wing iconoclasm" $(O B, 29)$. Political difference is cast in such categorical, almost existential terms that disagreement on any 
particular issue is assumed. Thus, if Forster is the sole template for understanding Smith's novel, the crucial question posed in the first scenes is missed: is a renewed national consensus (or something like it) possible in a post-Thatcher world?

If the departure from Forster's opening establishes the crucial question that haunts Smith's novel, the equally significant departure at the ending points to her relative pessimism regarding the capacity of beauty to adjudicate political or social tensions. Unlike Forster, Smith abandons even the pretense of joining the families through marriage at the end of On Beauty. No reconciliation between the warring families is possible; if their debate pauses, it is because of the catastrophically self-destructive choices of the antagonists. The more modest question on which the ending turns is whether Howard and Kiki's marriage might survive after the revelation of his sexual infidelity with Victoria (already having had an affair with a colleague, Claire Malcolm). At a public lecture on Rembrandt in which Howard is desperately attempting to salvage his career, he is startled to notice Kiki in the audience. Despite the awkwardness it produces for everyone at the event, Howard finds himself drawn to her-and suddenly having to reevaluate his analysis of Rembrandt's painting. As a committed poststructuralist, Howard rejects the concept of beauty as part of the mythology central to the production of eighteenth-century notions of the human. Yet he finds himself absorbed by the painting and Kiki, to the exclusion of everyone else in the lecture hall:

Howard made the picture [Hendrickje Bathing, 1654] larger on the wall, as Smith had explained to him how to do. The woman's fleshiness filled the wall. He looked out into the audience once more and saw Kiki only. He smiled at her. She smiled. She looked away, but she smiled. Howard looked back at the woman on the wall, Rembrandt's love, Hendrickje. $(O B, 443)$

Howard seems to appreciate a kind of beauty in the painting that he had previously attempted to deconstruct, and his silence resembles the kind of contemplation associated with aesthetic experience. This is no happy ending - the novel does no more than intimate that he might reunite with his estranged wife, who now shares briefly with him an appreciation of the beauty that they once experienced together as a young couple. But the scene does suggest a curious possibility: that a shared feeling or affective response might be more relevant to the longevity of their relationship than shared beliefs or attitudes. 
The minimal reconciliation intimated at the end of On Beauty is all the more striking in light of the plot shift necessary for it to have happened. The ideological rift between Howard Belsey and Monty Kipps that dominates the majority of the novel is replaced by the personal rift between Howard and Kiki. If modern forms of the aesthetic have historically been invoked to bridge social divisions, the unresolved debate between Howard and Monty provides an indication of the depth of such divisions at the beginning of the new millennium. That the two academics could have radically irreconcilable visions of aesthetics-much less politics, economics, and culture-throughout the novel suggests how much Smith takes the post-consensus political environment for granted. The shift, then, to the rift between Howard and Kiki renders the impediments to reconciliation at the end of the novel more manageable. Between Howard and Monty, reconciliation would require a radical and highly improbable conversion on the part of at least one of the characters - and their corresponding ideological convictions shown to be a sham. Between Howard and Kiki, in contrast, reconciliation would require only the restoration of an earlier stage their relationship. Shared aesthetic experience promises this as a possibility, affecting individuals not on a rational level, but a precognitive and putatively pre-ideological one. The novel has already indicated to readers that the estranged couple has had aesthetic experiences together (according to Jerome, Howard wooed Kiki by serenading her with a rendition of The Magic Flute). Indeed, early in their relationship, such experiences were key to overcoming the social divisions separating them: race, class, nationality.

The shift away from the representations of conflict discussed earlier in this essay is notable: while the notion of beauty continues to be evoked at moments of irreconcilable difference, it is called upon to provide a discourse for exploring what might be called the affective bases of citizenship rather than articulating a notion of Englishness inimical to Thatcherism. In her occasional pieces for The Guardian and elsewhere, Smith has repeatedly written about the importance of "affective responses" to reading. ${ }^{43}$ The emphasis on affect enables the apparently apolitical nature of her work. Because affect is a part of human nature, according to Smith, it becomes something with which all readers can identify. Thus, from White Teeth forward, multiculturalism and national identity can be topics without making any reader feel excluded or critiqued. Indeed, citizenship in Smith’s writings appears to be based neither on birthplace nor parentage, but a common humanity —one which is most fully revealed through 
the experience of reading. This is apparent in her declaration of the "truth" of fiction and the ways in which it expresses what she calls "my way of being in the world." 44 According to Smith, the "truth of your own conception" is something that emerges through a process of eliminating the biases introduced by one's historical, cultural, and national location, what she calls "all the dead language, the secondhand dogma, the truths that are not your own but other people's, the mottos, the slogans, the out-and-out lies of your nation, the myths of your historical moment[.]"45 Hence, the importance of leveling the antagonists in On Beauty, and the deliberate ambiguity regarding the future of Howard's and Kiki's relationship. Their struggles are not finally about managing intractable ideological differences but identifying their common humanity. Differences of politics, religion, and culture are the products of ideological biases imposed upon individuals, detaching them from their putatively natural citizenship.

The turn to an affect-based "natural" citizenship can certainly be read as a concession to the ubiquity of Thatcherism within the political realm-redefining the basis of citizenship as an acknowledgment that more direct political transformations are unlikely. Legitimate concerns along these lines have been raised by Lawrence Driscoll and others, whether "Smith's novel attempts to evade the issues of class that she is forced into." ${ }^{46}$ Yet a fair assessment of Smith's work would need at least to acknowledge its affinities with certain strands of cultural theory that call for rethinking ideology in light of the rise of neoliberalism since the 1980s. Brian Massumi's work to develop "an affective theory of late-capitalist power," in particular, makes a strong, if controversial, case for positing a nonideological space in the autonomic processes taking place below the threshold of conscious awareness. ${ }^{47}$ Massumi declares: "Affect holds a key to rethinking postmodern power after ideology. For although ideology is still very much with us, often in the most virulent of forms, it is no longer encompassing. It no longer defines the global mode of functioning of power." ${ }^{48}$ The move to locate opposition to global capitalism within the realm of the supposedly "subpersonal" involves reconsidering how ideology operates: does it encompass all cognitive and noncognitive neural processes, or, as Massumi suggests, does it operate on a narrower field of cognitive processes associated with rational deliberation? A generous reading of Smith's works, then, could view her focus on affect in relation to this question, whether or not a post-Thatcherite consensus would be possible by shifting its basis away from nationality to human biology. 
In contrast to On Beauty, Hollinghurst's The Line of Beauty demonstrates significant skepticism about the idea of a universal, natural citizenship based upon affect or feeling. After the catastrophic revelation of Nick's homosexual relations with Wani Ouradi-the son of one of the most prominent supporters of Thatcher-Nick is left literally on the street. Evicted from the Feddens' Notting Hill home, he imagines the impending day when he will be told that he is HIV-positive. Projecting forward into the future, Nick stares at the streets that will continue to buzz long after he is gone, and he finds himself overcome by an intense sensation that ultimately is defined as a response to beauty:

The emotion was startling. It was a sort of terror, made up of emotions from every stage of his short life, weaning, homesickness, envy and self-pity; but he felt that the self-pity belonged to a larger pity. It was a love of the world that was shockingly unconditional. . . . It wasn't just this street corner but the fact of a street corner at all that seemed, in the light of the moment, so beautiful. ${ }^{49}$

"Beauty" becomes the concept that enables Nick to recast his feelings of terror in nonthreatening terms. Evicted by the Feddens, forgotten by friends, ignored by passersby, he can nonetheless claim a connection to a "world" of people, if not to his fellow Britons. Nick does not need to reconcile himself to his immediate surroundings because he can find in his street corner this "world" to love. But the novel refuses to reaffirm Nick's claim, highlighting instead his sense of abandonment and limited economic prospects, particularly if his premonition about his medical diagnosis turns out to be accurate.

In both On Beauty and The Line of Beauty, then, beauty renders visible broader social tensions as they emerge through interactions between individuals. What would be the necessary conditions for a gay man in 1980s London to take his citizenship for granted, such that he would not need to imagine a beautiful future? What would be the necessary conditions for the warring academics in Smith's novel to recognize the contradictions between their publicly stated political positions and their personal infidelities, which reinforce patriarchal hierarchies and economic class privileges over the women with whom they have sex? Neither On Beauty nor The Line of Beauty suggests that beauty is ennobling; rather, it sensitizes readers to what $R$. Radhakrishnan has in another context called the constitutive unevenness that characterizes everyday life under global capitalism. ${ }^{50}$ More precisely, representations of beauty enable Smith's and Hollinghurst's fictional works to highlight the processes and rhetorical rationalizations 
utilized during the Thatcher era to accelerate disparities of wealth and privilege. Thatcher herself was always frank about the desirability of unevenness; as she put it in a retrospective speech entitled "Reflections on Liberty": "The single biggest intellectual error during my political lifetime has been to confuse freedom with equality. In fact, equality-being an unnatural condition which can only be enforced by the state-is usually the enemy of liberty." ${ }^{1}$ Unevenness signals the state's success in promoting the freedom of its citizenry by removing restrictions to private accumulation.

That experiences of beauty highlight the constitutive unevenness of wealth and privilege does not imply, however, that Hollinghurst subscribes to a model of aesthetic education through which individuals perfect sensory perception by being exposed to beauty. In The Line of Beauty, experiences of beauty are not portrayed as guiding critical judgments, revealing beastliness, or presenting resolutions to social tensions. Rather, such experiences tend to highlight the misjudgments of characters. The climactic example occurs at the event that promises to be the crowning achievement of Gerald Fedden's career: a house party held in Prime Minister Thatcher's honor. Nick briefly snatches the moment of glory away from Gerald and the men fawning over the Prime Minister by asking her to dance. In his mind, even Thatcher is swept up by the beauty of the moment, and Nick projects for himself a fantasy future standpoint from which to view his present: "Nick heard the whole episode already accruing its commentary, its history, as he went out with her among twitches of surprise, the sudden shifting of the centre of gravity, an effect that none of them could have caused and none could resist" $(L B, 335)$. Yet his perception of the moment, that Thatcher was dancing "breathless in his grip" is corrected when he subsequently views a photo of the event $(L B, 336)$. The photo portrays the Prime Minister with "a look of caution he hadn't been aware of at the time" $(L B, 355)$. Nick is revealed to be the character caught up in the moment, refusing to acknowledge any indications that the situation might not correspond fully to his aesthetic ideal. Even after Gerald cuts in on his dance, Nick continues to view the moment as beautiful. His aestheticism does not, in other words, enable him to diagnose unevenness in the Fedden household or the country more generally; to the contrary, it provides a way for him to overestimate his status in both. The error is made painfully apparent by Gerald's mistress at the end of the novel, as she and Nick are clearing out their respective personal effects from the Fedden home in the aftermath of a series of scandals that end Gerald's political career. Penny not only 
rebuffs Nick's efforts to project a sense of solidarity between them but also dismisses his cherished beliefs about the family's view of him. When Nick passionately declares that Gerald's wife is "an old friend," Penny deflates his claim simply by responding: "Well, I wonder if she feels the same about you" (OB, 436).

Hollinghurst emphasizes Nick's poor judgment—in matters political, aesthetic, and personal-from the very first paragraph of The Line of Beauty. Flipping through a book on Thatcher's 1983 electoral victory entitled Landslide!, Nick finds himself unable to judge whether the author is a hack and mordant analyst: "his faint smile, as he flipped through the pages, concealed his uncertainty as to which account was nearer the truth" $(L B, 3)$. Nick's uncertainty is not apparent in his conversations with others, however, with whom he freely dispenses judgments based upon his supposed aesthetic expertise. In an early date with this first male lover, Nick sounds off on Thatcherism and its "aesthetic poverty" $(L B, 93)$. But he seems unable to muster a clear rationale for his judgment, and he is quick to abandon it after his lover proves uninterested. Thus, when Nick actually meets the Prime Minister, his dismissal of her beastliness sounds hollow and flimsy. Nick may deride her sense of taste, declaring that "she looks like a country and western singer" ( $L B, 333)$; he may roast the men fawning upon her for their "fantastic . . heterosexual queenery" $(L B, 333)$; he may ostentatiously ignore the declaration by a fellow partygoer: "Isn't she beautiful" ( $L B, 329)$. But he fails to recognize his own participation, even as he stands compliantly in the receiving line at the Feddens' house party, kept in place by Gerald's fib that he is a don rather than a graduate student with little prospect of completing his degree.

Beauty, then, renders visible uneven distributions of wealth and privilege in Hollinghurst's novel not because aesthetic experiences undo the distortions produced by ideology but rather because the concept itself is intimately related to ideas of proportion or fit. This connection is most explicitly signaled when Nick reflects on the ogee curve, the emblematic "line of beauty" for William Hogarth (the source for the Hollinghurst's title). Nick believes that his idea of naming Wani's company "Ogee" has "a rightness to it" $(L B, 176)$. The name does indeed have a rightness to it, though not in the way that Nick imagines. As with the final scene, the term beauty highlights significant mismatches between beautiful objects and the world in which they reside. The company has no plan for making money, and folds once Wani contracts AIDS. Nick's own recognition that the ogee curve is "pure expression, decorative not structural" signals the vanity guiding 
his venture with Wani-a vanity that is tolerated by business associates because it is underwritten by the wealth produced by the grocery chain owned by Wani's father $(L B, 176)$. Like the curve for which it is named, the company cannot support itself or anything else. It is premised on a fantasy of producing something requiring immense labor and capital but having no utility-Nick's ideas for producing a high-end art magazine and a film version of Henry James's The Spoils of Poynton are ridiculously unprofitable projects.

Nick's frustration with Wani, however, indicates the ways in which exposure to beauty involves confronting the jarring elements of his life, the lack of "rightness." Snorting cocaine-what Wani slyly calls his "line of beauty" - does not silence nagging questions about the necessary obfuscations on which their covert relationship depends $(L B, 224)$. Does Wani have sex with his fiancée, a woman paid by his mother to present the necessary credentials of heterosexuality? Does Wani ever intend to tell his family about his relationship with Nick? Nick's reflections on beauty-whether in the form of the curves of his lover's buttocks or the prose of James - elicit powerful affective responses that undermine his willful complacency. Such disruptions do not lead to specific imperatives on how to act-reflecting on beauty does not, in other words, lead him to envision what a better relationship would look like. However, in an environment in which emotions are mobilized to support specific political or economic agendas, the unfocused disruptions Nick experiences are cast as profoundly unsettling.

The emphasis in Line of Beauty on the potentially unsettling aspects of aesthetic experience helps to clarify why beauty in anti-Thatcher representations is so often characterized in vague, ambiguous terms. The novels discussed in this essay have consistently been less interested in beautiful objects per se than in the discourse of beauty, and the implications of describing something or someone as beautiful. The ambiguity surrounding the term accentuates the point that even supposedly natural beauty is produced through a process of abstraction or aesthetic formalization, whereby the beautiful object is separated from its immediate circumstances and the historical conditions that produced it. Cocaine is beautiful to Wani only as long as he does not have to connect it to his addiction and withdrawal symptoms; it is beautiful in precisely the same way as the artworks owned by his family because he does not have to sully his hands with dealers, having Nick serve as his agent. The novel suggests, then, that the discourse of beauty provides a crucial occasion where the distortions produced by ideology become visible on the level of bodily affective responses. 
Wani's efforts to cast cocaine as beautiful, like Nick's efforts at the end of the novel to describe the world around him as beautiful, elicit physical responses in the characters that do not align with their rhetoric. Their cocaine habit testifies to the ever greater lengths they must go to suppress awareness of the misalignment. Wani and Nick need stronger and stronger drug-induced sensations to block their feelings of frustration, disappointment, and shame. So, the historical complaint against aesthetic ideology - that it promotes a dehumanizing, homogeneous ideal of politics - turns out to be the key to its capacity to highlight the constitutive unevenness on which Thatcherism depends. And hence the emphasis on the affective dimensions of aesthetic experience, highlighting their potential to disrupt the ideological uses to which beauty is often mobilized.

On this point, the turn to beauty in contemporary British fiction intersects with ongoing debates in affect theory. Critics of Massumi have focused on the political implications of his distinction between ideologically saturated emotions and pre-ideological affects. Ruth Leys and Sara Ahmed, for example, both make a strong case that Massumi's assertion of an autonomous, pre-ideological neural network not only reinstantiates an outdated mind-body dualism but also invests an inherent progressivism in the unpredictability associated with autonomic affective responses. Leys writes that the "new affect theory creates problems for progressive politics," in that it must locate political significance in the unpredictability of the so-called "subliminal visceral register in people's responses." As a result, "this unpredictability then becomes the basis for posthistoricist and post-Marxist 'hopefulness', or 'faith' in the possibilities of change." ${ }^{2}$ As I have tried to demonstrate, a similar determination to find in affective responses to beauty a cause for hope in the possibilities of social and political change has motivated British literary writers from David Hare to Zadie Smith. Reading contemporary British literature in relation to debates over affect theory helps to highlight the stakes for both: efforts to find cause for hope in neural networks or the aesthetic propensities of human nature are similarly motivated by a perceived need among cultural theorists and literary authors to counter the dominance of neoliberal thinking in the political discourses of the United States and Great Britain.

My analysis suggests that the basic function or ideological work that beauty is called upon to perform has not changed significantly in British fiction since the late 1980s and 1990s, even if there has been a notable shift away from the utopianism often apparent in literary works published in those decades. The utopian spaces of Barnes's and Coe's 
novels serve to delimit Thatcherism and neoliberalism more generally by positing nonideological spaces into which the artist as cultural critic can project a more just and humane state. The more affective disruptions that Smith and Hollinghurst associate with beauty do not present a utopian model of a political alternative, but they do still suggest the possibility that nonideological spaces might exist on the level of an individual's noncognitive corporeal processes or states. The compatibility of such a view with Thatcher's vision of self-reliant Britons raises an important question about the gradual disappearance of an embodied figure of beastliness in British fiction of the new millennium. Does the relative absence of such figures in On Beauty, The Line of Beauty, and other works including Monica Ali's Brick Lane (2003) and Kazuo Ishiguro's Never Let Me Go (2005) suggest that Thatcher is no longer a defining figure in British political and cultural life, or rather that Thatcherism has so thoroughly redefined a new national "consensus" that Thatcher herself as a physical presence has become superfluous?

\section{CODA}

When does the ghost stop haunting? When an actress known for, among other things, dressing up in rhinestones and singing rousing renditions of "Mamma Mia" works up her British accent to bring the ghost back to life-on-screen? When eerily familiar riots in London come and go, and the mad harridan herself does not return?

Both in the same year, 2011?

\section{Marquette University}

\section{NOTES}

An early version of this essay was presented at the 2012 annual meeting of the Modern Language Association, and I would like to thank the panel's organizer and chair, Kevin J. H. Dettmar, and the audience for their thoughtful feedback. I would also like to thank Leah Flack, Jodi Melamed, and the journal's reviewer for their advice.

${ }^{1}$ John Kyl, "Memories of Maggie," accessed 12 December 2011, http://www.nationalreview.com/articles/284956/memories-maggie-senator-jon-kyl.

${ }^{2}$ The notion that the "Thatcher revolution" of 1979 represents a break in literary history was apparent to some degree in scholarship of the 1990s such as D. J. Taylor, After the War: The Novel in English Society since 1945 (London: Chatto \& Windus, 1993); Robert Hewison, Culture and Consensus: England, Art and Politics since 1940 (London: Methuen, 1995); and Alan Sinfield, Literature, Politics, and Culture in Postwar Britain, 2nd ed. (London: Athlone Press, 1997). The notion has become more explicitly articulated and reaffirmed in a number of influential works including Dominic Head, The Cambridge Introduction to Modern British Fiction, 1950-2000 (Cambridge: Cambridge Univ. Press, 2002); Nick Bentley, ed., British Fiction of the 1990s (New 
York: Routledge, 2005); Brian Finney, English Fiction since 1984: Narrating a Nation (New York: Palgrave Macmillan, 2006); James F. English, ed., A Concise Companion to Contemporary British Fiction (Malden: Blackwell, 2006); Colin Hutchinson, Reaganism, Thatcherism and the Social Novel (New York: Palgrave Macmillan, 2008); and Amelia Howe Kritzer, Political Theatre in Post-Thatcher Britain: New Writing: 1995-2005 (New York: Palgrave Macmillan, 2008).

${ }^{3}$ For a thoughtful discussion of how the "turn" to beauty emerged in the arts, see Arthur C. Danto, The Abuse of Beauty: Aesthetics and the Concept of Art (Chicago: Open Court Press, 2003).

${ }^{4}$ Quoted in Kritzer, 8.

${ }^{5}$ Christopher Norris, What's Wrong with Postmodernism: Critical Theory and the Ends of Philosophy (Baltimore: Johns Hopkins Univ. Press, 1990), 16.

${ }^{6}$ For an excellent analysis of how beauty was mobilized to address perceived social ills at an earlier moment, see Douglas Mao, Fateful Beauty: Aesthetic Environments, Juvenile Development and Literature 1860-1960 (Princeton: Princeton Univ. Press, 2008).

${ }^{7}$ Claire Berlinski, "There Is No Alternative": Why Margaret Thatcher Matters (New York: Basic Books, 2008), xi. Berlinski's observation is useful in understanding why Thatcher became the representative figure of the 1980s. Thatcher cultivated her contradictory images- "Iron Lady" was supposed to be an oxymoron, and a derisive one at that. Long before she became the Iron Lady, however, she was manipulating often critical images of herself to reinforce her political credentials. Early in her career, she responded to criticisms of her inexperience and the sexism of many in her own party by portraying herself as a devoted housewife, Mrs. Dennis Thatcher. Such assertations were not intended to signal her deference to patriarchal authority, but rather to cast herself as a conviction-based politician unwavering in her commitments and unassailable within the spheres in which she claimed authority. Indeed, Thatcher was not unwilling to challenge patriarchal assumptions. Paul Johnson relates perhaps the most famous incident, which occurred at an anniversary dinner for the Institute of Economic Affairs. After being forced to sit through more than two hours of speeches, Thatcher was finally given her turn. She began by declaring: "As the tenth speaker and the only woman, I have this to say: the cock may crow but it's the hen who lays the egg" (quoted in Johnson, Heroes: From Alexander the Great and Julius Caesar to Churchill and De Gaulle [New York: Harper, 2007], 264). Thatcher herself proudly related the incident in a speech given at Hofstra University. See her "Reflections on Liberty," in The Political Legacy of Margaret Thatcher, ed. Stanislao Pugliese (London: Politico's Press, 2003), 1.

${ }^{8}$ Anthony Burgess, One Man's Chorus: The Uncollected Writings, ed. Ben Forkner (New York: Carroll \& Graf Publishers, 1998), 147-48.

${ }^{9}$ Quoted in Brendan Evans, Thatcherism and British Politics 1975-1999 (Thrupp: Sutton Publishing, 1999), 243.

${ }^{10}$ Roger Luckhurst elegantly makes the case for the significance of the literary and cultural spheres as sites of opposition to Thatcherism, arguing that Thatcher's punitive policies toward the cultural sphere "recognised that opposition to Thatcherism was increasingly cultural, since the parliamentary Labour Party was in disarray, left-wing local governments had powers progressively reduced, and union power was broken. Where political routes for opposition were legislated away, cultural moments of resistance multiplied" ("British Science Fiction in the 1990s: Politics and Genre," in British Fiction of the 1990s, 79). 
${ }^{11}$ Salman Rushdie, The Satanic Verses (1988; repr. New York: Random House, 2008), 278.

${ }^{12}$ Heather Nunn, Thatcher, Politics and Fantasy: The Political Culture of Gender and Nation (London: Lawrence \& Wishart, 2002), 172.

${ }^{13}$ Johnson, 266.

${ }^{14}$ Martin Amis, Money: A Suicide Note (1984; repr. New York: Penguin, 1986), 59.

${ }^{15}$ Hanif Kureishi, The Buddha of Suburbia (1990; repr. New York: Penguin, 1991), 258.

${ }^{16}$ See Mark Garnett, From Anger to Apathy: The British Experience Since 1975 (London: Jonathan Cape, 2007), 229.

${ }^{17}$ Head, 36.

${ }^{18}$ John Fowles, Wormholes: Essays and Occasional Writings, ed. Jan Relf (New York: Henry Holt and Company, 1998), 81.

${ }^{19}$ Jonathan Coe, The Winshaw Legacy or What a Carve Up! (1994; repr. New York: Vintage International, 1996), 159. Hereafter cited parenthetically by page number and abbreviated $W$.

${ }^{20}$ Julian Barnes, England, England (1998; repr. New York: Alfred A. Knopf, 1999), 264.

${ }^{21}$ For a more extended analysis of pastoralism in contemporary British fiction, see my Imagination and the Contemporary Novel (Cambridge: Cambridge Univ. Press, 2011), 55-81.

${ }^{22}$ Barnes, England, England, 249.

${ }^{23}$ Ryan Trimm, "Carving up Value: The Tragicomic Thatcher Years in Jonathan Coe," in Thatcher \& After: Margaret Thatcher and Her Afterlife in Contemporary Culture, ed. Louisa Hadley and Elizabeth Ho (New York: Palgrave Macmillan, 2010), 176.

${ }^{24}$ Salman Rushdie's short essay "A General Election" is emblematic of the incomprehension expressed by writers and scholars on the left in the face of Thatcher's reelection in 1983: "I had always thought that the British prided themselves on their common sense, on good old-fashioned down-to-earth realism. But the election of 1983 is beginning to look more and more like a dark fantasy, a fiction so outrageously improbable that any novelist would be ridiculed if he dreamed it up" (Imaginary Homelands: Essays and Criticism 1981-1991, [London: Granta Books, 1991], 159).

${ }^{25}$ Hutchinson, 64.

${ }^{26}$ Irony in pastoral works does not preclude a commitment to the ideals subject to scrutiny. Historically, it provided authors the means of signaling a separation between a purportedly simple worldview of the past and a complex worldview of the present, which cannot sympathize with or even entirely credit simplicity; see Imagination and the Contemporary Novel, 73.

${ }^{27}$ Quoted in Paul Gilroy, 'There Ain't No Black in the Union Jack': The Cultural Politics of Race and Nation (1987; repr. Chicago: Univ. of Chicago Press, 1991), 55.

${ }^{28}$ The failure of the left, according to Stuart Hall and Martin Jacques, was due to its failure to distinguish "Thatcherism and the world which Thatcherism claimed to represent and aspired to lead. ... The latter, as a consequence, looked omnipotent, as if it was in command of history" "Introduction," in New Times: The Changing Face of Politics in the 1990s [London: Lawrence and Wishart, 1989], 15).

${ }^{29}$ Raymond Williams, The Country and the City (New York: Oxford Univ. Press, 1973), 304.

${ }^{30}$ It is beyond the scope of this essay to do more than acknowledge the significant, often acrimonious differences among thinkers associated with the New Left, such as E. P. Thompson and Perry Anderson. Nor is it necessary for this essay's argument, which is not making a strict argument for causality between literary histories and sociopolitical theories, but rather for their convergence in anti-Thatcher representations. 
${ }^{31}$ See Sinfield, xi-xxx.

${ }^{32}$ Sinfield, 282.

${ }^{33}$ Since the seminal works of the New Left such as Williams's 1958 Culture and Society, perhaps the most cheished narrative of the left has been that the unfulfilled promise of the postwar consensus is preserved in working-class identities and culture, and that it might be mobilized into a political coalition that would fundamentally redefine British politics. Yet the uneasiness underlying this claim is never far beneath the surface. Williams's effort to identify a tradition of thinking tracing from Samuel Taylor Coleridge to R. H. Tawney that stresses "service to the community" in opposition to individualism is haunted by his recognition that community itself as an ideal has been felt very differently by different classes of British society (Culture and Society 1780-1950 [1958; repr. New York: Columbia Univ. Press, 1983], 328). Thus, his declaration that such a tradition represents "a major achievement which has done much for the peace and welfare of our society" is tinged by a kind of melancholia apparent in his frustration with what he saw as the betrayals of the Labour Party (328). His subsequent efforts to articulate a theory of "structures of feeling" in Marxism and Literature (1977) and later works highlight the challenges of identifying and articulating what he calls the "affective elements of consciousness and relationships" that might be mobilized politically (Marxism and Literature [Oxford: Oxford Univ. Press, 1977], 132).

${ }^{34}$ Gilroy, Postcolonial Melancholia (New York: Columbia Univ. Press, 2005), 89.

${ }^{35}$ Walter Benjamin lamented what he saw as the "metamorphosis of political struggle from a compulsory decision into an object of pleasure" in the literary works of middleclass authors whose "left-wing radicalism" is predicated on a pleasurable fatalism and the absence of any specific political activism ("Left-Wing Melancholy," in The Weimer Republic Sourcebook, ed. Anton Kaes, Martin Jay, and Edward Dimendberg [Berkeley: Univ. of California Press, 1994], 305). For Benjamin, the narratives on the political left risk shifting attention away from issues requiring activism, providing instead a consolation or pleasurable apathy. In many respects, critiques of the left by Norris, Anderson, and Gilroy can be seen as extending Benjamin's basic point.

${ }^{36}$ Thatcher \& After, 1.

${ }^{37}$ Hall and Jacques opened their introduction to the New Times project with the declaration: "The 'New Times' argument is that the world has changed, not just incrementally but qualitatively, that Britain and other advanced capitalist societies are increasingly characterized by diversity, differentiation and fragmentation, rather that homogeneity, standardisation and the economies and organizations of scale which characterized modern mass society" (11).

${ }^{38}$ Barnes, "Mrs. Thatcher Remembers," in Letters from London (New York: Vintage International, 1995), 220. Barnes reiterates this view twenty years later, in a review of the film The Iron Lady; see "Daddy's Girl," The New York Review of Books, 23 February 2012, access 21 May 2012, http://www.nybooks.com/articles/archives/2012/ $\mathrm{feb} / 23 /$ daddys-girl/?pagination=false.

${ }^{39}$ Steve Bell, "The End of the Affair," cartoon in The Guardian (2000), http://www. guardian.co.uk/Thatcher/graphic/0,5543,401742,00.html.

${ }^{40}$ Stephen Moss, "I don't make moral judgments': an interview with Alan Hollinghurst," The Guardian, 21 October 2004, http://www.guardian.co.uk/books/2004/ oct/21/bookerprize2004.bookerprize. In a 2007 interview for Readings, Hollinghurst reiterates his sense that Tony Blair has extended Thatcherism rather than challenged it. Asked about which policies in particular angered him, Hollinghurst responded: "There are all sorts. One would be the continuation of the Thatcherite policy of privatisation, 
flying in the horrendous face of established Labor policy and their election promises" ("Alan Hollinghurst," http://www.readings.com.au/interview/alan-hollinghurst).

${ }^{41}$ Zadie Smith, On Beauty (New York: Penguin, 2005), unpaginated acknowledgments. Hereafter cited parenthetically by page number and abbreviated $O B$.

${ }^{42}$ Philip Tew, Zadie Smith (New York: Palgrave Macmillan, 2010), 31.

${ }^{43}$ Smith, "Love, Actually," The Guardian, 31 October 2003, http://www.guardian. co.uk/books/2003/nov/01/classics.zadiesmith.

${ }^{44}$ Smith, "Fail Better," The Guardian, 13 January 2007, quoted in http://faculty. sunydutchess.edu/oneill/failbetter.htm.

${ }^{45}$ Smith, "Fail Better." Smith's vision of the self freed from historical and cultural location in many respects follows Elaine Scarry's vision of aesthetic education outlined in On Beauty and Being Just, which Smith acknowledges as a source for her novel. For Scarry, when a person witnesses something beautiful, he or she undergoes a "radical decentering," enabling the possibility of viewing the world in a more objective and ethical manner (On Beauty and Being Just [Princeton: Princeton Univ. Press, 1999], 111).

${ }^{46}$ Lawrence Driscoll, Evading Class in Contemporary British Literature (New York: Palgrave Macmillan, 2009), 62.

${ }^{47}$ Brian Massumi, Parables for the Virtual: Movement, Affect, Sensation (Durham: Duke Univ. Press, 2002), 43.

${ }^{48}$ Massumi, 42.

${ }^{49}$ Hollinghurst, The Line of Beauty (New York: Bloomsbury, 2004), 438. All references to this text are hereafter cited parenthetically by page number and abbreviated $L B$.

${ }^{50} \mathrm{R}$. Radhakrishnan argues that unevenness is the defining condition of global capitalism, most obviously experienced through the disparities between the "West" and the "Rest," but definitive of every geopolitical location; see Theory in an Uneven World (Oxford: Blackwell Publishing, 2003), vi-x.

${ }^{51}$ Thatcher, "Reflections on Liberty," 2.

${ }^{52}$ Leys, "The Turn to Affect," Critical Inquiry 37.3 (Spring 2011), 460-61n48. See also Sara Ahmed, The Cultural Politics of Emotion (Edinburgh: Edinburgh Univ. Press, 2004), 40n4. 